\title{
Stem Cell Course in the Middle East: Science Diplomacy and International Collaborations During the Arab Spring
}

\author{
Balazs Sarkadi • Gerald Schatten
}

Published online: 7 June 2011

(C) The Author(s) 2011. This article is published with open access at Springerlink.com

\begin{abstract}
In April 2011, an international advanced course and workshop entitled "Frontiers in Human Pluripotent Stem Cells" and an International Congress on Fertility and Genetics (http://www.fertigen.com.jo/ConferenceDetails. aspx) was held in Amman Jordan hosted by the Jordanian Society of Fertility and Genetics under the auspices of the International Cell Research Organization (ICRO), a UNESCO associated NGO. The Congress President Dr. Zaid Kilani, with Dr. Abdel Latif Abu Khadra, President of the Jordanian society for Fertility and Genetics, Dr. Rana Dajani of the Hashemite University of Jordan, and their Organizing Committee proved to be an excellent organizers and dedicated physician-scientists and, focusing on fertility, genetics and stem cells in a wide range of advanced therapeutic applications. Brilliant course participants included trainees, scientists and clinicians from the Greater Middle East. The lectures and practical sessions, presented by internationally acknowledged scientists, included over-
\end{abstract}

Drs. Sarkadi and Schatten are the Vice-President and President of the International Cell Research Organization (ICRO), respectively. The authors declare no potential conflicts of interest.

B. Sarkadi

Hungarian Academy of Sciences,

Dioszegi 64,

1113 Budapest, Hungary

G. Schatten $(\square)$

Pittsburgh Development Center,

University of Pittsburgh School of Medicine,

Pittsburgh, PA 15213, USA

e-mail: schattengp@upmc.edu views of recent achievements in pluripotent stem cell research, emphasizing the role of both the embryonic (ES) and induced pluripotent stem (iPS) cells. A major emphasis was placed on the clinical achievements in germ cell and umbilical cord stem cell transplantation issues, and on the potential of fast and successful prenatal and pre-implantation molecular genetics diagnostics. The organization of the stem cell course in the Holy Land especially emphasized that issues of "eternal life" and "rejuvenation" are already at hand-at least in the pluripotent stem cell research field. In the lively atmosphere of the course about 60 participants had heated discussions on the possibility and ethics of advanced prenatal diagnostics, and on regulatory issues reflecting the need of separation of clinically effective versus unapproved, unwarranted stem cell treatments. An open discussion of many ethical issues, reflecting profound differences in religion and medical tradition in the different countries, made this course exceptionally interesting for both teachers and trainees.

Keywords Stem cells · Middle East - International - Science Diplomacy · Jordan · Induced Pluripotency · Germ cells · Global cooperation · Education · Training · PGD · Fertility · Genetics

In the middle of a wide-spread unrest in the Arab world, this April 2011, the capital of Jordan, Amman, hosted an international advanced course and workshop on "Frontiers in Human Pluripotent Stem Cells" and an International Congress on Fertility and Genetics (http://www.fertigen. 


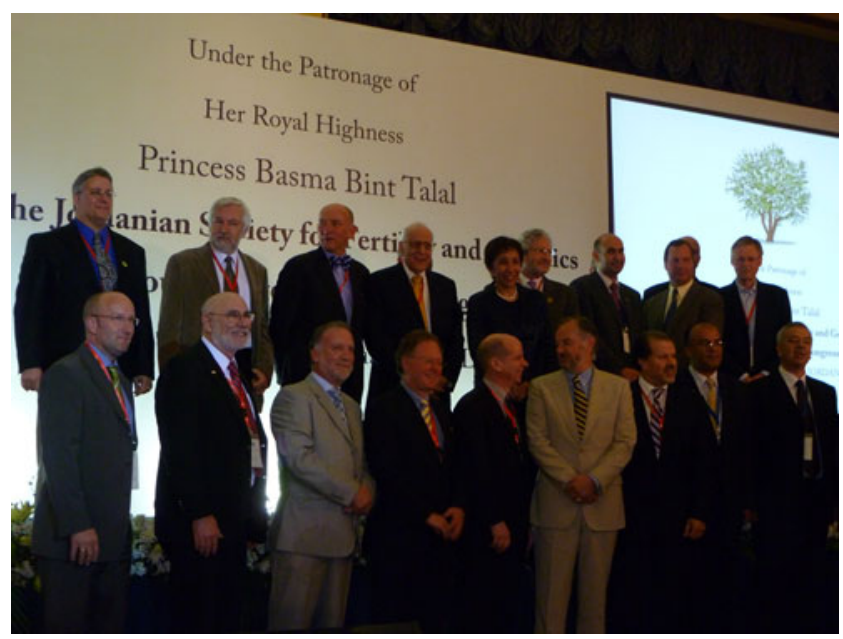

Fig. 1 Opening Session of the JORDIAN SOCIETY FOR FERTILITY AND GENETICS Congress and Commencement for the Stem Cell Workshop. High Royal Highness Princess Basma Bint Talal of Jordan (Center). Dr. Zaid Kilani is directly to her right and the authors (B.S.; 3rd right and G.S.; her left) are also in this figure together with many of the speakers

com.jo/ConferenceDetails.aspx). The aim of the advanced training course, organized by the International Cell Research Organization (ICRO), and the Jordanian Society of Fertility and Genetics, was to attract students and clinicians from the neighboring countries and demonstrate the fantastic recent achievements in the area of stem cell research. The lectures and practical sessions, presented by internationally acknowledged scientists, included overviews of recent achievements in pluripotent stem cell research, emphasizing the role of both the embryonic (ES) and induced pluripotent stem (iPS) cells. A major emphasis was placed on the clinical achievements in germ cell and umbilical cord stem cell transplantation issues, and on the potential of fast and successful prenatal and preimplantation molecular genetic diagnostics.

The recently "rejuvenated" ICRO, with its halfcentury tradition of educating and mentoring promising young scientists with outstanding advanced training courses in the developing world, assured a high quality of this event. Participation of local and international speakers and live laboratory demonstrations made the course a temporary center of advanced clinical technologies. Course and Congress participants came from throughout the Greater Middle East, including Bahrain, Egypt, Iran, Iran, Libya, the Palestinian Territories, Syria and, of course, our host country, the Hashemite Kingdom of Jordan. The organization of the stem cell course in the Holy Land especially emphasized that issues of "eternal life" and "rejuvenation" are already at hand - at least in the pluripotent stem cell research field.

In the lively atmosphere of the course about 60 participants had heated discussions on the possibility and ethics of advanced prenatal diagnostics, and on regulatory issues reflecting the need of separation of clinically effective versus unapproved, unwarranted stem cell treatments. An open discussion of many ethical issues, reflecting profound differences in religion and medical tradition in the different countries, made this course exceptionally interesting for both teachers and students. Dr. Zaid Kilani, the Congress President, together with Dr. Abdel Latif Abu Khadra, President of the Jordanian society for Fertility and Genetics, Dr. Rana Dajani of the Hashemite University of Jordan, and their Organizing Committee proved to be an excellent organizers and dedicated physician-scientists and, focusing on fertility, genetics and stem cells in a wide range of advanced therapeutic applications.

The International Congress, closely attached to the advanced course, brought both scientific events to a magnificent social gathering. The Congress was opened by Jordanian Princess H.R.H. Basma Bint Talal, the late King Hussein's sister and King Abdullah's Aunt (Fig. 1). To a great joy of the guest scholars, she gave an excellent free talk in English on the need of modern biological science to flourish even further in the Muslim world, so well known about its eminent classical scholars. She especially emphasized the need for modern medicine in the area of fertility, thus liberating women and promoting their health at this part of the world as well. As we learned later, in fact, at the time of need she went to the Mayo clinic to donate her bone marrow for King Hussein's stem cell therapy.

Course organizers noted that it is rare in the Middle East to have in depth training courses and this gave the participants the flavor of how investigations are conducted in the United States and Europe as well as opening new horizons and opportunities to speak with internationally renowned scientists. In addition to the many physicianscientists in the workshop and congress, there were about a dozen fundamental doctoral trainees in the course and perhaps twice that number in the Congress.

Culture, art - and as we believe - science could easily bring together people even with widely different views and ambitions, and thus may make this troubled part of the world a new melting pot of scientific achievements and advanced medical technologies. 
Open Access This article is distributed under the terms of the Creative Commons Attribution Noncommercial License which permits any noncommercial use, distribution, and reproduction in any medium, provided the original author(s) and source are credited.

\section{Appendix}

International Cell Research Organization (ICRO) proudly announces a new laboratory course entitled: FRONTIERS IN HUMAN PLURIPOTENT STEM CELLS

\section{Amman JORDAN April 20-23, 2011}

Under the Auspices of the:

\section{JORDANIAN SOCIETY FOR FERTILITY AND GENETICS AND THE FARAH HOSPITAL}

Organized by: Abdel Latif Abu Khadra, MD (Jordan); Rana Dajani, PhD (Jordan); Zaid Kilani, MD (Jordan); Maya Mitalipova, PhD (USA, Kazakhstan); Gerald Schatten, PhD (USA)

Advisory Committee: H. Baharvand PhD (Iran), P. Braude MD (UK), H. Gourabi PhD (Iran), F. Kilani, MD (Jordan), S. Kilani MD (Jordan), J. Pruszak MD (Germany, USA), M. Sarhan, MD (Jordan), P. Schlegel MD (USA),

S. Schlatt PhD (Germany), J. Shay PhD (USA)

\section{Patient-Specific Disease-Expressing Pluripotent Stem Cells for Medical Discoveries}

8:30 AM Welcome and Introduction

8:45 AM Pluripotent Stem Cells—G. Schatten

9 AM Lab Demo: Culture, passaging and characterizations -

C. Simerly, C. Easley

9:45 Marcus Hughes, MD, PhD (US) Stem Cells and PGD Frontiers

10:45 Patient-Specific PSCs Established by Induced Pluripotency

Lab Demo: PSC derivations by iPS; Chas Easley, C. Simerly

1:00 PM Clinical Observations on Therapeutic Opportunities in Male infertility- Peter Schlegel, MD

1:20 Lab Demo: Male Germ Cell Transplantation - Stefan Schlatt, Dr. rer. nat.

3 PM Neuroprogenitors from PSCs—Jan Pruszak, MD

Lab Demo: Neuroprogenitor differentiation

3:40 PM Challenges and Opportunities iPSCs for Clinical Introduction;

B. Sarkardi (Hungary)

4 PM Umbilical Cord Stem Cell Transplantation-Mahmoud Sarhan, MD

4:20 PM Cancer Stem Cells—Jerry Shay, PhD 


\section{THURSDAY}

9:00-9:30

9:30-10:00

10:00-10:30

10:30-11:00

II

11:00-11:45

11:45-12:30

12:30-2:00

III

2:00-2:30

2:30-3:00

3:00-3:30

3:30-4:00

IV

4:00-4:30

4:30-5:00

5:00-5:30

FRIDAY

$\mathrm{V}$

9:00-9:30

9:30-10:00

10:00-10:30

10:30-11:00

VI

11:00-11:45

$11: 45-12: 30$

$12: 30-2: 30$

VII

2:30-3:00

3:00-3:30

3:30-4:00

4:00-4:30

VIII

4:30-5:00

5:00-5:30

5:30-6:00

\section{REPRODUCTIVE SURGERY}

\section{TITLE}

Endometrioma and IVF: to touch or not to touch

The long term effects of electrocautery of the ovaries in PCOS

Embryo transfer can we improve it?

Coffee break

\section{KEYNOTE LECTURES}

TITLE

Progesterone induced blood flow in improving pregnancy outcome

Modern ART in today's society

Lunch break session: Hot controversial Topics in ART

MALE INFERTILITY

TITLE

What's new with diagnosing sperm defects?

Non-obstructive azoospermia:Evolution of treatment

Repeated micro-dissection TESE: is there a limit?

Coffee break

REPRODUCTIVE GENETICS

TITLE

Clinical aspects of globozoospermia

Genetics of infertility : how to clone human genes solely involved in infertility phenotype

What have stem cells taught us about early human embryology

\section{INFERTILITY MANAGEMENT}

TITLE

The pros and cons of IUI

GnRH antagonists are safer than agonists

OHSS risk reduction/prevention in ART

Coffee break

\section{KEYNOTE LECTURES}

TITLE

Managing male infertility in the 21 st century: Optimizing diagnostic and treatments by mechanistic understandings and avoiding intractable male infertility

Preimplantation Genetics in 2011: The Promise and

The Controversies

Lunch break

IVF LAB

TITLE

New developments on sperm selection for ICSI

Objective markers of oocyte and embryo viability

Impact of lifestyle factors and antioxidative treatment on sperm analysis results (WHO AND MSOME criteria) Coffee break

CLINICAL ART

TITLE

Evidenced based management of poor ovarian response

"Single Embryo Transfer: The way ahead?"

closing remarks

\section{SPEAKER}

Juan Garcia-Velasco

Fulco Van Der Veen

Rene Frydman

SPEAKER

Salim Daya

Jurgis Gedis Grudzinskas

SPEAKER

Christopher Barratt

Peter Schlegel

Abdel Latif Abu Khadra

SPEAKER

Christopher Barratt

Stephane Vivilli

Peter Braude

SPEAKER

Willem Ombelet

Hesham Al Inany

Peter Humaidan

SPEAKER

Gerald Schatten

Mark Hughes

SPEAKER

Willem Ombelet

Marcos Meseguer

Johannes Wogatzky

SPEAKER

Stratis Kolibianakis

Peter Brinsden

Peter Brinsden
COUNTRY

USA

COUNTRY

COUNTRY

Spain

Netherland

France

COUNTRY

Canada

UK

COUNTRY

UK

USA

Jordan

UK

France

UK

COUNTRY

Belgium

Egypt

Denmark

COUNTRY

USA

COUNTRY

Belgium

Spain

Austria

Greece

UK

UK 